\title{
KEPEMIMPINAN DALAM GEREJA SEBAGAI PELAYANAN
}

\author{
Pdt. Robert P. Borrong, Ph.D. ${ }^{1}$
}

\begin{abstract}
Abstrak
Kepemimpinan dalam gereja bukanlah pelaksanaan kekuasaan atau otoritas manusia melainkan suatu kegiatan pelayanan. Pelayanan yang ditujukan kepada Yesus Kristus, Pemilik dan Kepala Gereja. Gereja ada karena panggilan untuk mewartakan Kerajaan Allah di dunia. Oleh sebab itu kepemimpinan tidak terutama berkenaan dengan penataan organisasi gereja tetapi berkenaan dengan penataan pelayanan gereja kepada Tuhan dan bagi dunia. Kepemimpinan gereja tidak bertujuan membuat organisasi gereja dengan baik, tetapi menata organisasi gereja dengan baik supaya pelayanan dan kesaksian kepada dunia berjalan dengan baik.

Pemimpin-pemimpin dalam gereja adalah pelayan-pelayan yang bekerja dengan sukacita dan sukarela karena adanya panggilan dari Tuhan bagi mereka untuk mengambil bagian dalam karya Yesus Kristus di dunia yaitu memberitakan keeselamatan yang telah diberikan kepada dunia oleh dan melalui pengorbanan Yesus Kristus di atas kayu salib. Oleh sebab kepemimpinan adalah panggilan, maka kepemimpinan dijalankan dengan sukarela dan sukacita. Itulah hakekat kepemimpinan sebagai pelayanan gereja. Menjadi pemimpin yang melayani berarti menjadi pemimpin yang memberikan dirinya untuk mengabdi kepada Tuhan, bukan kepada manusia.
\end{abstract}

Kata-kata kunci: Pemimpin, pelayan, panggilan, organisasi, ekklesia, kesaksian, persekutuan, pelayanan, pengurus, wibawa, motivator, kordinator, fasilitator.

\section{Pengantar}

Pemimpin adalah orang yang mengambil inisiatif dan mempengaruhi. Leighton Ford memahami para pemimpin sebagai "take the lead" dan "more people to follow them". ${ }^{2}$ Artinya seorang pemimpin adalah pengambil inisiatif dan perencana, sekaligus diikuti karena dihargai. Bertolak dari pemahaman tersebut maka dapat dikatakan bahwa kepemimpinan adalah cara mewujudkan rencana melalui keikutsertaan orang lain. Mempengaruhi orang lain, merupakan kata kunci dalam kepemimpinan. Berikut adalah beberapa contoh pemimpin yang memahami kepemimpinan sebagai menggerakkan orang lain. ${ }^{3}$ Jack Welch (CEO General Electric 19882000, terkenal sebagai CEO terbaik abad 20): "Sukses kepemimpinan adalah mengembangkan orang lain". John C. Maxwell, penulis dan pembicara kepemimpinan): "Pemimpin adalah orang yang mengetahui jalannya, menjalaninya dan memandu orang lain menempuhnya".

\footnotetext{
${ }^{1}$ Dosen Etika Kristen dan Teologi Kontekstuap pada Sekolah Tinggi Filsafat dan Teologi Jakarta

${ }^{2}$ Leighton Ford, Transforming Leadership, Downers Grove: Intervarsity, 1991, 25.

3 Jansen Sinamo dan Agus Santosa, Pemimpin Kredibel, Pamimpin Visoner, Cet 2, Jakarta: Institut Darma Mahardika, 2012, xv.
} 
Kepemimpinan adalah cara-cara pemimpin memengaruhi, mengajak, meyakinkan, mengatur, dan memberdayakan orang-orang yang dipimpin untuk memahami, menyikapi dan memiliki visi dan misi bersama sehingga seluruh jajaran digetarkan dan digerakkan untuk ikut serta memberikan yang terbaik bagi terwujudnya visi dan misi bersama atas dasar falsafah dan sistem nilai yang dianut. ${ }^{4}$ Cara, mengandung arti seni dan metode. Walaupun cara-cara perlu, ternyata pribadi pemimpin sangat penting dan menentukan. Seperti yang dikatakan oleh Leighton Ford, "Leadership is first of all is not something one does, but something one is". 5 Jadi apapun kemampuan yang dimiliki pemimpin, pada akhirnya yang menentukan kepemimpinannya adalah pribadinya. Memengaruhi, mengajak, mendorong, mengatur dan memberdayakan, akhirnya sangat ditentukan oleh pribadi sang pemimpin. Keterampilan dan teknik memengaruhi orang lain memang diperlukan tetapi keterampilan dan teknik saja tidak cukup. Tidak gampang membuat seseorang untuk mengikuti kehendak orang lain, baik pasif maupun aktif, kalau sekedar mengandalkan teknik. Diperlukan kekuatan khusus yang membuat orang lain suka ikut dan berperan. Seorang pemimpin diikuti, bukan karena terpaksa atau terbujuk, melainkan karena sukarela, karena percaya kepada pemimpin. Dwight Eisenhower, (Presiden ke-34 Amerika Serikat) mengatakan "Kepemimpinan adalah seni membuat orang melakukan sesuatu dengan cara-cara yang kita lakukan, tetapi dengan penuh kerelaan". 6 Seorang pemimpin adalah seorang yang didengar, diikuti dan ditaati dengan sukarela dan sukacita.

Kekuatan khusus setiap pemimpin tentu berbeda. Dalam teori-teori kepemimpinan, kekuatan khusus itu biasanya disebut sebagai "kekuasaan" (otoritas). Otoritas yang menjadi andalan seorang pemimpin dalam menjalankan kepemimpinannya sangat menentukan tingkat keberhasilan kepemimpinan orang tersebut. Setiap pemimpin membutuhkan otoritas, tetapi keberhasilan kepemimpinan sangat ditentukan oleh sumber otoritas yang diandalkan pemimpin. Karena otoritas seorang pemimpin berkaitan erat dengan kekuasaan, maka kita perlu memahami dari mana kekuasaan seorang pemimpin bersumber? John French dan Bertram Raven menyebutkan 5 sumber kekuasaan: ${ }^{7}$

1. Jabatan/kedudukan (Legitimate power). Misalnya seorang Rektor atau Dekan berhak mengatur dosen dan mahasiswa yang ada di lingkungan kekuasaannya.

2. Keahlian/keterampilan (Expert power). Misalnya seorang dokter ditaati perintahnya mengenai larangan makan jenis makanan tertentu demi kesehatan karena keahliannya.

3. Pemaksaan/kemampuan menghukum (Coercive power). Misalnya seorang majikan (dengan paksa) dapat memberhentikan karyawan dari pekerjaannya, atau memaksanya mengerjakan apa saja yang dikehendakinya.

4. Kemampuan memberi imbalan (Reward power). Kekuasaan yang dilandaskan pada kemampuan memberi imbalan, misalnya seorang kaya yang dapat memaksa orang lain melakukan pekerjaan tertentu berdasarkan imbalan.

5. Kualitas pribadi (Referent power). Para pemimpin kharismatis yang ditaati dan dihormati karena wibawa pribadinya. Contoh: Mahatma Gandhi.

\footnotetext{
${ }^{4}$ Jonathan Parak, Pembelajar dan Pelayan, Jakarta: Institut Darma Mahardika, 2002, 293-294.

${ }^{5}$ Leighton Ford, Transforming Leadership, 39.

${ }^{6}$ Jansen Sinamo dan Agus Santosa, Pemimpin Kredibel, Pamimpin Visoner, xvii.

${ }^{7}$ https://www.mindtools.com/pages/article/newLDR 56.htm diakses, 6 Juni 2017.
} 
Apakah yang menjadi sumber otoritas atau kekuasaan pemimpin-pemimpin di gereja sebagai pemimpin-pemimpin rohani? Mengapa di gereja perlu pemimpin-pemimpin? Guna menjawab pertanyaan ini terlebih dahulu harus dipahami karakter khusus dari pada gereja sebagai organisasi yang memerlukan pemimpin-pemimpin.

\section{Gereja sebagai Organisasi}

Organisasi berasal dari kata organ yang berarti alat yang bersifat hidup untuk melakukan tugas tertentu. Organisasi dapat didefinisikan sebagai suatu bentuk persekutuan manusia yang disusun secara teratur dalam suatu ikatan resmi yang melakukan tugas tertentu dalam kerjasama agar tujuan yang telah ditetapkan bersama tercapai. ${ }^{8}$ Apakah gereja dapat disebut sebagai organisasi? Kata gereja merupakan terjemahan kata Yunani ekklesia yang secara harafiah berarti dipanggil keluar. Ek artinya keluar, kaleo berarti memanggil. Jadi ekklesia berarti dipanggil ke luar dari kehidupan lama dan masuk ke dalam persekutuan dengan Yesus Kristus. ${ }^{9}$ Mengapa gereja disebut demikian? Karena Yesus menggunakan kata itu dalam Matius 16:18 ketika mengatakan: "Aku mendirikan ekklesian (jemaatKu)". Kemudian dalam 1 Petrus 2:9-10 rasul Petrus mendefinisikan gereja sebagai persektuan orang-orang yang dipanggil ke luar dari kegelapan dunia, masuk ke dalam terang Tuhan Yesus. Oleh sebab itu kata gereja dalam bahasa Yunani kadang-kadang disebut sebagai kuriakon atau kuriakos yang berarti milik kepunyaan Tuhan. ${ }^{10}$ Baik kata ekklesia maupun kata kuriakon sejajar dengan arti kata qahal atau qehilah ${ }^{11}$ dalam Perjanjian Lama yang juga diartikan persekutuan atau jemaat atau perhimpunan.

Kata ekklesia dan ekklesias ditemukan dalam Matius 18:17, digunakan Yesus menunjuk kepada persekutuan jemaat. Karena itu gereja sebagai ekklesia bersifat lokal berarti suatu persekutuan yang nampak dalam bentuk perkumpulan warga jemaat. ${ }^{12}$ Selanjutnya, di dalam Perjanjian Baru, persekutuan jemaat ini diungkapkan dengan berbagai sebutan yang menggambarkan identitas dan hakekatnya. Misalnya dalam 1 Korintus 12 dan Epesus 1:22-23; $3: 10,21$; 5:22-32, disebutkan bahwa gereja adalah komunitas atau persekutuan yang hidup, dinamik dan berfungsi untuk melanjutkan pelayanan Kristus di dunia. Dalam ayat-ayat di atas ini ditekankan bahwa ekklesia (jemaat, gereja) dipanggil untuk tujuan yang jelas yaitu menjadi alat (organ) penyelamatan Allah di dunia. Hal ini jelas dari definisi ekklesia yang dirumuskan dalam 1 Petrus 2:9: "Tetapi kamulah bangsa yang terpilih, imamat yang rajani, bangsa yang kudus, umat kepunyaan Allah sendiri, supaya kamu memberitakan perbuatan-perbuatan yang besar dari Dia (Yesus Kristus), yang telah memanggil kamu keluar dari kegelapan kepada terangNya yang ajaib". Tujuan ekklesia ialah memberitakan perbuatan Kristus atau memberitakan Kerajaan Allah. Maka misi gereja adalah memberitakan kebaikan Allah yang nyata dalam diri dan karya Yesus Kristus kepada dunia. Untuk melaksanakan tugas itu dengan baik dan lancar maka ekklesia harus menata

\footnotetext{
${ }^{8}$ Chris Hartono, Peranan Organisasi Bagi Gereja, Jakarta: BPK Gunung Mulia, 1978, 6.

${ }^{9}$ Allen W. Graves, A Church At Work: A Handbook of Church Polity, Nashville: Convention Press, $1972,4$.

${ }^{10}$ Henk ten Napel, Kamus Teologi Inggris - Indonesia, Jakarta: BPK Gunung Mulia, 2002, 77.

${ }^{11}$ Georg Fohrer, (ed.), Hebrew and Aramic Dictionary of the Old Testament, trs. W. Johnstone, Berlin/New York: Walter de Gruyter, 1973, 243.

12 J.D. Douglas (ed.), Ensiklopedi Alkitab Masa Kini, Jilid I, A-L, terj. Tim Bina Kasih, Cet. 7, Jakarta: Yayasan Komunikasi Bina Kasih, 2002, 332.
} 
dirinya menjadi organ-organ yang hidup. Maka manajemen (penataan) gereja menjadi sesuatu yang mutlak.

Karena ekklesia adalah perkumpulan orang-orang yang ber-koinonia tentu mereka datang dengan kekhasan masing-masing. Mereka berinteraksi dan berkomunikasi maka diperlukan suatu arah dan tujuan bersama sehingga setiap anggota berfungsi menuju tujuan yang satu yaitu pembangunan ekklesia sebagai tubuh Kristus untuk memberitakan kebaikan Allah kepada dunia. Gereja ada untuk dunia, bukan untuk dirinya saja. Gereja harus berkarya untuk dunia dan berbuah untuk dunia. Dengan demikian gereja adalah organisasi yang hidup dan dinamik dikepalai oleh Yesus Kristus sendiri, harus mengalami pertumbuhan dan menghasilkan buah, sebab tujuan gereja selaku ekklesia adalah mewartakan Kerajaan Allah. Penataan gereja sebagai organisasi bertujuan supaya panggilan dan tugas pemberitaan Kerajaan Allah dapat terlaksana dan tercapai dengan baik.

Menurut Allen B. Graves, gereja dapat didefinisikan secara organisasi dalam arti bahwa gereja mempunyai anggota, pemimpin dan melakukan hubungan-hubungan, ${ }^{13}$ sehingga perlu ditata dengan baik. Tetapi organisasi gereja tidak berhenti atau berakhir dengan adanya organisasi yang tertata dengan baik melainkan terus berproses dalam pemberitaan yang baik dan benar tentang keselamatan dalam Yesus Kristus yang memberikan kebaikan kepada dunia. Itulah buah dari organisasi gereja. Gereja ada dan menata dirinya untuk dunia, untuk kesaksian dan pelayanan kepada dunia. Inilah yang dikenal dengan tri-tugas panggilan gereja yaitu bersekutu (koinonia), bersaksi (marturia) dan melayani (diakonia). Ketiga tugas panggilan ini dilakukan supaya gereja dapat bertumbuh, baik secara kualitas (kedewasaan iman anggota jemaat) maupun secara kuantitas (pertambahan jumlah anggota dan juga sarana-prasarana) yang dibutuhkan untuk terus bersaksi dan melayani dunia. Kepemimpinan dalam organisasi gereja sangat dibutuhkan karena adanya kebutuhan pertumbuhan gereja dalam melaksanakan tugas panggilannya.

Ralph H. Elliott, seperti dikutip oleh Virgil, mengemukakan adanya empat jenis pertumbuhan gereja yaitu pertumbuhan internal, ekspansi, ekstensi dan lintas budaya. ${ }^{14}$ Pertumbuhan internal berarti pertumbuhan ke dalam jemaat yang mencakup struktur, spiritual dan pengakuan iman. Pertumbuhan ekspansi pertambahan jumlah anggota karena faktor biologis (anak-anak), perpindahan anggota gereja lain (transfer) dan melalui pekabaran Injil. Pertumbuhan ekstensi adalah pertumbuhan gereja yang murni dihasilkan oleh pekabaran Injil yang dilakukan secara sistematik. Pertumbuhan lintas budaya, adalah pertumbuhan gereja pada budaya lain melalui proses pekabaran Injil. Singkatnya, gereja harus bertumbuh, baik secara kualitatif atau intensif maupun kuantitatif atau ekstensif. Kita bisa melihat bahwa gereja tidak boleh bersifat statis dan mempertahankan status quo (kemapanan). Gereja tidak boleh bertahan hanya pada zona nyaman melainkan harus mengembangkan dirinya. Dalam rangka pengembangan gereja inilah maka sangat dibutuhkan pemimpin-pemimpin dalam gereja. Itulah hakekat gereja dengan tugas panggilannya menjadi gereja yang bersekutu, bersaksi dan melayani. Itu alasan mengapa di dalam organisasi gereja perlu ada pejabat gereja.

Kehadiran pejabat gereja bertugas untuk memberitakan Firman Tuhan dan membina warga gereja agar terjadi perkembangan dan perubahan. Ibarat Kereta Api, pejabat-pejabat gereja adalah lokomotif yang berfungsi menarik dan mendorong gerbong kereta yaitu seluruh warga gereja sehingga berjalan kearah tujuannya. Tujuan gereja itu adalah mewujudkan pembangunan gereja

\footnotetext{
${ }^{13}$ Allen W. Graves, A Church At Work: A Handbook of Church Polity, 3.

14 John Virgil, Kompleksitas Pengembangan Gereja, Jakarta: Yayasan Kasih Imanuel, 2001, 16-18.
} 
sebagai tubuh Kristus. Jabatan gereja ada supaya gereja memiliki pemimpin sebagai organisasi di dunia. Pejabat gereja memang tidak identik dengan pemimpin gereja, sebab jabatan diberikan, sedangkan kepemimpinan dijalankan. Oleh sebab itu kepejabatan berkait erat dengan kepemimpinan. Artinya pejabat harus menjadi seorang pemimpin, walaupun pemimpin tidak selalu berarti pejabat.

\section{Jabatan Gerejawi}

Di dalam gereja, Allah sendirilah yang menjadi pusat semua pemimpin. Segala kuasa ada ditangan Dia, yaitu Yesus Kristus yang kepadanya telah diberikan segala kuasa di bumi dan di sorga (Matius 28:18). Dan karena itu semua pemimpin tidak boleh mengandalkan kekuatan dan kekuasaannya sendiri melainkan mendasarkan diri pada kuasa atau otoritas dari Allah. Allah sendiri yang memanggil dan memilih semua pemimpin dalam gereja menjadi pelayan-pelayan (Roma 12:4-8; I Korintus 12:28-30; Epesus 4:11-16) untuk membangun persekutuan jemaat. Kita menerima panggilan dan pilihan itu sebagai kharisma (karunia, talenta) dan bukan kapasitas atau karena kompetensi pribadi kita. Oleh sebab itu para pemimpin harus memimpin dengan rendah hati seperti hamba yang melayani (Markuas 10:43-44). Dalam Perjanjian Baru, para pejabat gereja disebut sebagai presbiter yang berarti tua-tua. Sejak tahun 100 masehi jabatan presbiter dibedakan dari episcopos, dan sejak itu para pemimpin dalam gereja mulai dipahami secara structural dan piramidal. ${ }^{15}$ Reformasi Gereja pada abad ke 15 antara lain mengkritik struktur gereja dengan kepemimpinan pyramidal tersebut. Namun demikian, sampai sekarang system pemerintahan gereja ada aneka ragam. Papalisme dalam gereja Katolik, Episkopal dalam gereja Anglican dan Lutheran. Presbiterial (Sinodal) dalam gereja Calvinis dan Kongregasional dalam gereja-gereja Injili dan pentakostal.

Gereja adalah persekutuan yang dihimpunkan oleh Kristus untuk mendengarkan FirmanNya. Kehadiran para pejabat dalam gereja tidak dapat dilepaskan dari dua fungsi gereja yang sangat penting tadi yaitu untuk memberitakan Firman Allah dan melayankan sakramen-sakramen. Calvin mengajarkan bahwa dalam gereja ada empat jabatan, yang ditetapkan oleh Kristus sendiri sebagai Kepala Gereja, yaitu pendeta (pastor), pengajar (doctor), penatua (ancient harafiah orang yang lanjut usia) dan diaken atau syamas, ${ }^{16}$ meskipun ada tiga fungsi lain yang disebutkan dalam Epesus 4:11-13 yaitu rasul, nabi dan penginjil. Alasan sebagaimana dijelaskan dalam catatan kaki dibawah ini, terutama terkait dengan paham Calvin tentang fungsi utama gereja yaitu untuk memberitakan Firman Tuhan dan melayankan sakramen, mengajar orang percaya untuk mengenal Allah, mengawasi kehidupan jemaat dan melayani orang-orang serba kekurangan di dalam persekutuan jemaat. Menurut Calvin, presbuteroi terdiri dari pendeta dan penatua bersama-sama menjadi senat atau dewan (majelis) mendidik, mengawasi dan menilik (warga) jemaat. ${ }^{17}$ Tugas

\footnotetext{
${ }^{15}$ Robert P. Borrong, Melayani Makin Sungguh: Signifikansi Kode Etik Pendeta bagi Pelayanan Gereja-gereja di Indonesia, Jakarta: BPK Gunung Mulia, 2016, 48.

${ }^{16}$ Christian de Jonge, Apa itu Calvinisme? Jakarta: BPK Gunung Mulia, 2011, 103.

17 John Calvin, Institutes of The Christian Religion, trans. Henry Beveridge, Grand Rapids: Eerdmans, Michigan, 1989, 318-319, Calvin tidak menyetujui fungsi nabi, rasul dan penginjil yang disebutkan dalam Epesus 4:11-13, karena menurutnya jabatan nabi hanya ada dalam PL, sedangkan fungsi rasul lebih terkait dengan penugasan keluar gereja untuk memberitakan Injil sebagaimana dicatat dalam Markus 16:15. Penginjil hanyalah fungsi yang
} 
utama pada pejabat gereja adalah memberitakan Firman Tuhan sesuai dengan prinsip sola scriptura (hanya oleh Alkitab). Para pejabat gereja dipanggil untuk memberitakan Firman Tuhan dan membina orang-orang percaya. ${ }^{18}$ Belakangan, fungsi pengajar sepenuhnya diserahkan pada lembaga pendidikan, sehingga tinggal 3 fungsi yaitu pendeta, penatua dan syamas.

Jabatan-jabatan di dalam gereja dibedakan berdasarkan fungsi bukan kekuasaan. Karena itu struktur kepemimpinan gereja juga bukanlah struktur kekuasaan melainkan struktur fungsional yaitu berdasarkan karunia-karunia tadi. Pendeta tidak lebih tinggi dari penatua, penatua tidak lebih tinggi dari diaken atau syamas, bahkan tidak lebih tinggi dari pada warga jemaat. Itu sebabnya pelayan-pelayan gereja disebut majelis (council) yang berarti bersama-sama melayani atau komunitas pelayan-pelayan. Kata majelis dalam bahasa Yunani disebut Synedrion artinya duduk bersama. Tetapi dalam masayarakat Yahudi pada zaman Perjanjian Baru, Synedrin (diterjemahkan Sanhedrin) dimaknai sebagai pengadilan atau pimpinan agama tertinggi, setara dengan Mahkamah Agung dalam struktur pengadilan modern. Akan tetapi tradisi kehadiran presbiter (tua-tua) dalam gereja tua-tua bangsa Yahudi yang disebut Zaken yaitu para pemimpin bidang keagamaan. ${ }^{19}$ Itu sebabnya di dalam gereja, para pemimpin atau pejabat gereja disebut presbiter yang berarti tuatua, terdiri dari pendeta, penatua dan syamas.

\section{Pemimpin dan Kepemimpinan Gereja}

Siapakah pemimpin dalam gereja? Tidak lain dari pada Yesus Kristus kepala gereja. Kuasa dan otoritas mutlak dalam gereja adalah Allah. ${ }^{20}$ Secara mutlak, Allah adalah otoritas tunggal dalam gereja. Menurut Eka Darmaputera, God is the Leader, not merely a leader. ${ }^{21}$ Pemimpin dalam gereja adalah hamba-hamba yang diberikan otoritas untuk melayani dengan wibawa Kristus ( 2 Korintus 13:10; band. Kisah Rasul 1:8). Itu sebabnya para pemimpin dalam gereja disebut sebagai pelayan-pelayan sebab tugas pokok mereka adalah memperlengkapi warga gereja untuk pekerjaan pelayanan dan pembangunan Tubuh Kristus. Oleh sebab itu para pemimpin harus menyadari bahwa mereka bukan penguasa dalam gereja melainkan pelayan-pelayan yang lebih berperan sebagai motivator, fasilitator, moderator, dan kordinator dalam pengelolaan organisasi gereja. Itu berarti tidak ada struktur kepemimpinan yang bersifat hierarkhis melainkan representatif. ${ }^{22}$ Dalam hal ini pemimpin dipandang selaku orang-orang dipanggil oleh Yesus Kristus (Epesus 4:11-16) untuk memperlengkapi warga mewujudkan Kerajaan Allah di dunia.

\footnotetext{
lebih rendah yaitu dilakukan sebelum ada jemaat. Dengan demikian fungsi presbiter yang terdiri dari pendeta (pastor), penatua (episcopos) dan syamas (deacon) memang dilihat oleh Calvin sebagai fungsi pelayan jemaat secara internal.

${ }^{18}$ Christian de Jonge, Apa itu Calvinisme?, 101.

19 J.B. Taylor, "Tua-tua", dalam: J.D. Douglas, dkk (peny.), Ensiklopedi Alkitab Masa Kini, Cet.6, Jakarta: Yayasan Komunikasi Bina Kasih/OMF, 2002, 493.

${ }^{20}$ Michael J. Anthony and James Estep, Jr (eds.), Management Essentials for Christian Ministries, Nashville:

Broadman \& Holman Publishers, 2005, 40.

${ }^{21}$ Eka Darmaputera dkk, Kepemimpinan Kristiani, Jakarta: Sekolah Tinggi Teologi Jakarta, 2001, 3.

22 Peter F. Rudge, Management in the Church, London: McGraw-Hill Book Company, 1976, 9 ff.
} 
Karena para pemimpin adalah orang-orang terpanggil maka di dalam gereja sebenarnya tidak ada istilah karier, karena para pelayan adalah orang-orang yang memenuhi panggilan, mereka bukan orang-orang yang mengejar profesi melainkan orang-orang yang melakoni pelayanan. ${ }^{23}$ Pemahaman ini berlaku bukan hanya untuk pendeta, penatua dan syamas, tetapi juga untuk mereka yang bekerja selaku pengurus apapun dan pengerja di dalam gereja. Mereka memahami dirinya sebagai pelayan-pelayan dalam keseluruhan pelayanan gereja. Pemimpin dalam gereja harus menerapkan otoritas dan kekuasaan dari Allah, bukan otoritas dan kekuasaan dari diri pelayan.

Dari 5 sumber kekuasaan yang disebut French dan Raven di bagian pengantar, saya menggaris bawahi dua yang terpenting yang menjadi sumber kekuasaan pemimpin gereja/Kristen yaitu legitimasi kekuasaan dan kualitas pribadi. Apakah sumber legitimasi kekuasaan para pemimpin gereja? Itulah panggilan dari Tuhan dan pemilihan oleh jemaat. Para pemimpin dalam gereja adalah orang-orang yang terpanggil oleh Tuhan sendiri untuk terlibat dalam pekerjaan pelayanan di Gereja. Sumber kepemimpinan gereja adalah Yesus Kristus sendiri yang memanggil pelayan-pelayan sebagaimana ditulis dalam Epesus 4:11-16. Di dalam gereja Allah sendirilah yang menjadi pusat semua pemimpin. Segala kuasa ada ditangan Dia, yaitu Yesus Kristus yang kepadanya telah diberikan segala kuasa di bumi dan di sorga (Matius 28:18). Dan karena itu semua pemimpin tidak boleh mengandalkan kekuatan dan kekuasaannya sendiri melainkan mendasarkan diri pada kuasa atau otoritas dari Allah. Allah sendiri yang memanggil dan memilih semua pemimpin dalam gereja menjadi pelayan-pelayan (Roma 12:4-8; I Korintus 12:28-30; Epesus 4:11-16) untuk membangun persekutuan jemaat. Para pemimpin gereja menerima panggilan dan pilihan itu sebagai kharisma (karunia, talenta) dan bukan kapasitas atau karena kompetensi pribadi. Oleh sebab itu para pemimpin harus memimpin dengan rendah hati seperti hamba yang melayani (Markuas 10:43-44).

Kehadiran para pemimpin dalam gereja diyakini sebagai panggilan dari Tuhan menurut Epesus 4:11-16 tadi. Karena pemimpin adalah orang-orang yang terpanggil, maka mereka menjalankan kepemimpinan mereka sesuai dengan maksud dan tujuan panggilan mereka. Anthony D'Souza mengatakan bahwa ada tiga gambaran kepemimpinan menurut Injil Yesus Kristus, yang dalam bahasa Inggris semuanya dimulai dengan huruf S yaitu Servant (Pelayan), Shepherd (gembala) dan Steward (Pengurus). Kepemimpinan yang sejati bagi Pemimpin Gereja/Kristen, adalah mengikuti Yesus sebagai Pelayan, Gembala dan Pengurus. ${ }^{24}$ Kualitas seorang Pemimpin Gereja/Kristen tidak ditentukan oleh kepintaran atau keterampilan memimpin tetapi oleh kesungguhan dalam melayani, menggembalakan dan mengurus umat yang dipercayakan kepadanya. Bagi Calvin tingkah laku seorang Kristen yang paling penting bukanlah kesempurnaan melainkan kesungguhan. ${ }^{25}$ Itu sebabnya kepemimpinan dalam gereja bukan pagelaran kekuasaan melainkan pelaksanaan pelayanan.

\section{Pemimpin Pelayan}

\footnotetext{
${ }^{23}$ Peter F. Rudge, Management in the Church, 21.

${ }^{24}$ Anthony D'Souza, Ennoble, Enable, Empoer, Kepemimpinan Yesus Sang AlMasih, Jakarta: Gramedia, 2009, xxiiixxiv.

25 James A Whayte, “Calvinist Ethics” in James F. Childress (ed.), A New Dictionary, London: SCM Press, $1986,71$.
} 
Para pemimpin Kristen memahami dasar kepemimpinan sebagai panggilan untuk menjadi pemimpin yang melayani (Markus 10:42-45). Menurut Tomatala, seorang pemimpin Kristenterpanggil oleh kepada tugas dab tanggung jawab sebagai seorang pelayan dengan status ebagai hamba Allah. ${ }^{26}$ Jadi pemimpin bukan pejabat atau penguasa yang memerintah, melainkan pelayanan yang mengemban tugas panggilan dari Tuhan sendiri. Dasar kepemimpinan yang melayani adalah Yesus Kristus sendiri. Ada banyak contoh dari kepemimpinan Yesus sebagai pelayan, tetapi yang terpenting dari semuanya adalah keteladanan. Yesus selalu memimpin dengan memberi teladan.

Pemimpin Gereja/Kristen yang memberdayakan pertama-tama adalah pemimpin yang melayani dengan teladan. Pemimpin seperti ini sebenarnya tidak hanya adala dalam gereja, tetapi mestinya ada pada semua pemimpin. Robert Greenleaf menyebutkan bahwa kepemimpinan yang melayani adalah kewajiban semua pemimpin. Menurut dia, pemimpin adalah seorang pelayan sebab memimpin berarti melayani: "a servant leader is one who leads in order to serve". ${ }^{27}$ Para pemimpin hanya bisa memberdayakan orang-orang yang dipimpin melalui keteladanan. Para pemimpin gereja yang bisa memberi teladan adalah pemimpin gereja yang menyadari dan menghayati panggilannya seperti Yesus Kristus yaitu melayani dan bukan dilayani (Markus 10:45). Keteladanan Yesus dalam melayani antara lain dinyatakan ketika Ia bersedia membasuh kaki murid-murid-Nya (Yohanes 13:14-15).

Karena Tuhan sendiri yang menjadi satu-satunya pemilik kuasa dalam gereja maka para pemimpin gereja adalah pelayan-pelayan atau hamba (yang disebut doulos dalam bahasa Yunani). Secara harafiah, kata Yunani: Doulos artinya pelayan atau hamba setara dengan kata Ibrani: Eved dalam bahasa Ibrani. ${ }^{28}$ Kata ini dipakai baik dalam arti sekuler maupun dalam arti rohani. Doulos atau Eved digunakan dalam arti mengabdikan diri pada orang lain, misalnya kepada orang yang lebih tinggi status atau kedudukannya, tetapi terutama kepada TUHAN. ${ }^{29}$ Mengapa menjadi pelayan atau hamba? Dibedakan doulos/eved yang diterima karena terpaksa dan doulos/eved yang diterima dengan sukarela. Para pemimpin dalam gereja adalah doulos/eved yang diterima dengan sukarela dan sukacita, sedangkan doulos/eved sekuler diterima karena terpaksa.

Di dunia sekuler, orang menjadi hamba karena terpaksa. Tidak ada orang yang bersedia atau mau menjadi hamba secara sukarela. Orang menjadi hamba karena kalah perang atau karena hutang tidak bisa dibayar. Itu kategori hamba atau pelayan terpaksa. Tidak semua pekerjaan sekuler menjadi hamba atau pelayan dilakukan karena terpaksa. Doulos atau Eved juga dapat diartikan sebagai pekerjaan atau job yaitu melayani orang lain karena dibayar atau diberikan imbalan atau upah. Dalam hal ini menjadi pelayan disamakan dengan profesi: PRT, OB, TKbn dll. Doulos atau Eved sebagai pekerjaan rendahan atau hina dijalankan karena tidak ada pekerjaan lain, walaupun ada juga yang menjalankannya dengan sukarela.

Tetapi di dalam gereja, menjadi hamba adalah kesediaan menerima sukarela dan sukacita panggilan dan pilihan Tuhan seperti Musa, Nabi-nabi dan rasul-rasul. Oleh karena itu kehambaan atau kepelayanan dalam gereja adalah kehambaan dan kepelayanan sukarela. Maka tidak boleh dijalankan dengan kuasa untuk menguasai apalagi menindas orang lain. Menjadi doulos thou Theu

\footnotetext{
${ }^{26}$ Yakob Tomatala, Kepemimpinan yang Dinamis, Jakarta: Leadership Foundation, 1997, 46.

${ }^{27}$ Robert K. Greeleaf, Servant Leadership: A Journey into the Nature of Legitiamte Power and Greatness, New York: Paulist Press, 1977, 10.

${ }^{28}$ Georg Fohrer, (ed.), Hebrew and Aramic Dictionary of the Old Testament, 194.

${ }^{29}$ John Virgil, Kompleksitas Pengembangan Gereja, 83.
} 
atau ebed Yahweh adalah pilihan untuk menjadi pelayan yang melayani dengan sukarela dan sukacita. Pelayanan dilakukan karena alasan altruisme dan filantropis serta adanya panggilan khusus. Justru menata para pelayan jauh lebih sulit dari menata pegawai atau karyawan. Soalnya melayani dengan sukarela dan sukacita bisa juga menjadi suka-sukanya.

\section{Pemimpin Gembala}

Yesus adalah pemimpin gembala. Dia adalah Gembala yang Baik yang memberikan nyawaNya bagi domba-domba-Nya (Yohanes 10:11). Walaupun hanya pendeta yang disebut gembala, tetapi sesungguhnya semua pemimpin dalam gereja adalah gembala. Ini dilandaskan pada istilah gembala yang mula-mula menunjuk kepada Tuhan sebagai gembala (Mazmur 23) dan Yesus Kristus sebagai gembala yang baik (Yohanes 10), tetapi kemudian kepada Petrus Yesus menugaskan supaya ia menggembalakan domba-domba (warga jemaat) yang dipercayakan kepadanya (Yohanes 21: 15-17) dan Petrus menasihati para presbiter supaya menggembalakan kawanan domba Allah dengan pengabdian diri (1 Petrus 5:1-3). Tugas utama kepemimpinan shepherd (gembala) adalah pengabdian diri dan pengorbanan. Pemimpin gembala adalah pemimpin yang menemu-kenali setiap domba, membela dan menjaganya dari serangan predator dan rela berkorban. Maka pemimpin gembala adalah pemimpin yang fokus pada tanggungjawabnya, mengorbankan kepentingannya demi untuk kepentingann umat. ${ }^{30}$ Sebagai pemimpin gembala, apakah Anda mengenal semua warga jemaat dengan baik? Apakah mengetahui persoalan dan ancaman yang mereka hadapi? Mengetahui pergumulan dan kebutuhannya? Apakah Anda telah hadir dan siap membela bagi mereka?

\section{Pemimpin Pengurus}

Estafet kepemimpinan dari Yesus kepada Pemimpin-pemimpin Gereja/Kristen ditandai dengan pemberian talenta-talenta. Dalam perumpamaan Yesus tentang talenta tersirat makna bahwa kepada setiap orang diberikan tanggung jawab (Matius 25:14-30). Pemimpin pengurus adalah pemimpin yang tidak duduk-duduk saja menikmati posisi yang diberikan kepadanya melainkan pemimpin yang mempertanggungjawabkan kepercayaan (trust) yang diberikan kepadanya. Ciri utama pemimpin pengurus (steward leader) adalah pertanggung-jawaban (accountability). ${ }^{31}$ Pemimpin sebagai pengurus harus bertindak sebagai bendahara yang dapat mempertanggunjawabkan bukan hanya talenta-talenta tetapi juga umat yang dipercayakan kepada mereka melalui pengelolaan yang baik dan benar. Supaya pemimpin dapat bertanggung-jawab maka ia harus memiliki kejujuran dan integritas sebagai seorang yang dapat dipercaya.

Pemimpin Pengurus harus memiliki kejujuran dan berintegritas berarti berkata benar dan mengatakan yang sesungguhnya, bersikap adil dan bertindak adil, penuh kasih dan peduli pada orang lain. Inilah karakter (character) dasar seorang pemimpin pengurus. Selain itu, pemimpin pengurus harus juga memiliki komtetensi (competence), komitmen (commitment) dan belas kasih (compassion). Para pemimpin pengurus adalah pemimpin berkarakter dan transparan dalam segala hal, itu sebabnya mereka dipercaya. Kompenesi, komitmen dan belas kasih adalah bagian dari karakter pemimpin. Maka yang terutama bagi seorang pemimpin gereja adalah karakternya.

\footnotetext{
${ }^{30}$ Anthony D'Souza, Ennoble, Enable, Empoer, Kepemimpinan Yesus Sang AlMasih, 37.

${ }^{31}$ Anthony D'Souza, Ennoble, Enable, Empoer, Kepemimpinan Yesus Sang AlMasih, 44.
} 
Apakah karakter pemimpin? Borrong, ${ }^{32}$ mengemukakan 6 karakter dasar pemimpin Kristen yaitu kerendahan hati seperti Musa (Keluaran 3:11), suka mendengar seperti Samuel (1 Samuel 3:10), taat dan responsive seperti Yesus (Filipi 2:8-9) dan Yosua (Yosua 1:10), Berani dan penurut seperi Yesus (Markus 12:5, Matius 23:28, Lukas 12:1) dan Yesaya (Yesaya 6:8), rela berkorban seperti Yesus (Markus 10:45, Yohanes 1015) dan jujur seperti Yesus (Matius 22:16, Markus 12:14).

Para pejabat dalam gereja bukan sekedar manajer, walaupun gereja perlu dikelola sesuai manajemen modern. Pejabat gereja adalah pemimpin yang diberikan otoritas lebih dari sekedar manajer. Anthony D'Souza, menolong kita melihat 10 perbedaan pemimpin dan manajer sebagai berikut: ${ }^{33}$

\begin{tabular}{|l|l|}
\hline Pemimpin & Manajer \\
\hline Melihat ke masa depan & Memperhatikan masa sekarang \\
\hline $\begin{array}{l}\text { Menentukan gambar besar mengenai tujuan } \\
\text { dan arah }\end{array}$ & Memastikan setiap detail diperhatikan \\
\hline $\begin{array}{l}\text { Menciptakan komitmen sehingga segala } \\
\text { sesuatu berjalan dengan lebih baik }\end{array}$ & $\begin{array}{l}\text { Melakukan control untuk memastikan segala } \\
\text { sesuatu berjalan dengan baik }\end{array}$ \\
\hline $\begin{array}{l}\text { Menciptakan masa depan yang lebih baik } \\
\text { dengan menangkap peluang yang ditimbulkan } \\
\text { oleh berbagai perubahan }\end{array}$ & $\begin{array}{l}\text { Mengatasi masalah sekarang dengan menagani } \\
\text { kesulitan yang yang disebabkan oleh berbagai } \\
\text { perubahan }\end{array}$ \\
\hline Berfokus pada hasil & \begin{tabular}{l} 
Berfokus pada proses \\
\hline $\begin{array}{l}\text { Berfokus pada apa yang benar dan } \\
\text { mengajarkannya }\end{array}$
\end{tabular} $\begin{array}{l}\text { Berfokus pada perilaku bermasalah dan } \\
\text { berusaha memperbaikinya melalui konseling, } \\
\text { pelatihan dan pembinaan }\end{array}$ \\
\hline $\begin{array}{l}\text { Mengilhami orang-orang untuk melakukan } \\
\text { yang terbaik }\end{array}$ & $\begin{array}{l}\text { Memastikan bahwa orang-orang bekerja } \\
\text { dengan jujur untuk mendapatkan gaji }\end{array}$ \\
\hline $\begin{array}{l}\text { Menciptakan visi untuk tahun-tahun ke depan } \\
\text { Mengorganisasikan dan merencanakan untuk } \\
\text { mencapai target tahun ini }\end{array}$ \\
\hline $\begin{array}{l}\text { Menciptakan system yang lebih efisien } \\
\text { melampaui standar prosedur operasional } \\
\text { (SOP) }\end{array}$ & $\begin{array}{l}\text { Membuat kebijakan dan standar prosedur } \\
\text { operasional (SOP) yang efisien }\end{array}$ \\
\hline Berfokus pada efektivitas & Berfokus pada efisien \\
\hline
\end{tabular}

Selanjutnya, Warren Bennis membedakan pemimpoin dengan manajer sebagai berkit: ${ }^{34}$

\begin{tabular}{|l|l|}
\hline Pemimpin & Manajer \\
\hline Melakukan hal-hal yang benar & Melakukan hal-hal dengan benar \\
\hline Melakukan inovasi & Mengatur \\
\hline Mengilhami & Mengendalikan \\
\hline Melihat jangka Panjang & Melihat jangka pendek \\
\hline
\end{tabular}

\footnotetext{
32 Robert P. Borrong, "Etika dan Karakter Kepemimpinan”, dalam: Eka Darmaputera dkk, Kepemimpinan Kristiani, 73-77.

${ }^{33}$ Anthony D'Souza, Ennoble, Enable, Empower, 63.

${ }^{34}$ Seperti dikutip Anthony D'Souza, Anthony D'Souza, Ennoble, Enable, Empower, 64.
} 


\begin{tabular}{|l|l|}
\hline Menayakan apa dan mengapa & Menanyakan bagaimana dan kapan \\
\hline Menciptakan & Meniru \\
\hline Menolak pemapanan & Menerima kepmapanan \\
\hline
\end{tabular}

Dari contoh-contoh perbedaan pemimpin dengan manajer, kita dapat mengevaluasi apakah selama ini kita telah bertindak sebagai pemimpin atau manajer? Di dalam gereja, tentu saja dibutuhkan baik pemimpin maupun manajer. Tetapi supaya gereja berkembang dan maju, pemimpin lebih dibutuhkan dari pada sekedar manajer. Oleh sebab itu, para pejabat gereja harusnya berperilaku sebagai pemimpin-pemimpin dan bukan sekedar manajer-manajer. Organisasi gereja dapat berkembang kalau dipimpin oleh pejabat-pejabat gereja yang memiliki visi untuk menumbuhkan gereja sebagai dasar dan alas an memperlengkapi warga gereja bagi pembangunan tubuh Kristus, sesuai Epesus 4:11-16.

Ada berbagai model pengorganisasian gereja, seperti diuangkapkan oleh Lyle E. Schaller dan Charles A. Tidwell, yaitu model partisipasi (aktifkan seluruh warga jemaat), model representasi (diwakili hanya oleh presbiter), model performance (diwakili oleh suatu badan semacam eksekutif komiten atau satgas, atau komisi ad hoc), model tugas dan misi (beberapa satuan tugas pelayanan dan tidak memerlukan administrasi), model senioritas (bergantung kepada para senior dalam jemaat). ${ }^{35}$ Saya menggaris bawahi model partisipasi sebagai model pengorganisasian gereja yang ideal sesuai teks Epesus 4. Model ini menganut prinsip" "anggota yang terlibat adalah anggota yang aktif dan anggota yang aktif adalah anggota yang terlibat". ${ }^{36}$ Supaya gereja bisa bertumbuh, maka program gereja harus pertama-tama dan terutama diorientasikan kepada kualitas yaitu kedewasaan iman warga jemaat dan bukan sekedar kepada kuantitas yaitu pertumbuhan jumlah anggota dan jumlah persembahan jemaat. Bukan yang banyak itu yang baik, tetapi yang baik itu yang banyak. Kalau iman anggota sudah terbangun dan dapat difasilitasi para pemimpin maka pertumbuhan kuantitas dengan sendirinya terjadi.

Saya menilai bahwa selama ini, kepemimpinan gereja-gereja memang sudah fokus dalam membangun kehidupan iman (pertumbuhan intensif), tetapi pembangunan iman yang hanya bersifat seremonial (mengutamakan upacara dan liturgi), sesuatu yang bersifat rutin saja, kurang memperhatikan kualitas iman warga jemaat. Para pemimpin gereja ke depan harus lebih kreatif dan proaktif mencari dan menciptakan cara-cara untuk membuat warga jemaat dewasa dalam iman sehingga bersemangat dan berpartisipasi penuh dalam pembangunan Tubuh Kristus. Oleh sebab itu program gereja harus berorientasi pada pendewasaan iman umat. Ketika semua umat menjadi dewasa, maka jemaat berkembang karena seluruh warganya menjadi warga yang proaktif membangun gereja, dengan demikian para pemimpin hanya berfungsi sebagai kordinator dan fasilitator. Selain itu, sesuai dengan hakekat gereja sebagai persekutuan yang harus bersaksi (marturia), maka pertumbuhan ekstensif gereja perlu juga mendapat perhatian. Pertumbuhan ekstensif gereja-gereja kita masih sebatas pertumbuhan biologis dan mungkin sedikit transfer, tetapi belum menyentuh pertumbuhan ekspansif. Ini adalah pekerja rumah para pemimpin gereja ke depan.

${ }^{35}$ Lyle E. Schaller \& Charles A. Tidwell, Creation Church Administration, Nashville/New York: Abingdon, 1975, 25.

${ }^{36}$ Lyle E. Schaller \& Charles A. Tidwell, Creation Church Administration, 26. 


\section{Penutup}

Pada masa lalu para pemimpin gereja harus lebih banyak berperan sebagai motivator, karena warga jemaat masih kurang pemahaman dan oleh karena itu mereka lebih bersikap pasif. Kebanyakan pemimpin berfungsi memotivasi umat agar suka berpartisipasi dalam melakukan tugas-panggilan gereja. Sekarang ini, para pemimpin harus melangkah lebih jauh dengan memerankan fungsi kordinator dan fasilitator sebab kebanyakan warga gereja sudah memamahami tugas-panggilan gereja dan suka aktif kalau diberikan peran. Inilah tugas para pemimpin jemaat-jemaat pada masa kini.

Selain pemimpin yang berfungsi sebagai kordinator dan fasilitator, di dalam gereja dibutuhkan juga pemimpin kreatif dan proaktif karena warga gereja membutuhkan pemimpun-pemimpin yang bisa mengarahkan mereka menyalurkan bakat-bakat dan potensi warga gereja untuk pembangunan kehidupan iman, baik intensif (kualitas) maupun ekstensif (kuantitas) sehingga gereja semakin maju dan memerankan tugas panggilannya sebagai organisasi yang bersekutu, bersaksi dan melayani secara maksimal dan optimal.

\section{Daftar Rujukan}

Anthony, Michael J., and James Estep, Jr (eds.), Management Essentials for Christian Ministries, Nashville: Broadman \& Holman Publishers, 2005.

Borrong, Robert P., Melayani Makin Sungguh: Signifikansi Kode Etik Pendeta bagi Pelayanan Gereja-gereja di Indonesia, Jakarta: BPK Gunung Mulia, 2016.

Calvin, John, Institutes of The Christian Religion, trans. Henry Beveridge, Grand Rapids: Eerdmans, Michigan, 1989.

Childress James F., (ed.), A New Dictionary, London: SCM Press, 1986.

D’Souza, Anthony, Ennoble, Enable, Empower, Kepemimpinan Yesus Sang AlMasih, Jakarta: Gramedia, 2009.

Darmaputera, Eka dkk, Kepemimpinan Kristiani, Jakarta: Sekolah Tinggi Teologi Jakarta, 2001

Douglas J.D., (ed.), Ensiklopedi Alkitab Masa Kini, Jilid I, A-L, terj. Tim Bina Kasih, Cet. 7, Jakarta: Yayasan Komunikasi Bina Kasih, 2002.

Fohrer, Georg (ed.), Hebrew and Aramic Dictionary of the Old Testament, trs. W. Johnstone, Berlin/New York: Walter de Gruyter, 1973

Ford, Leighton, Transforming Leadership, Downers Grove: Intervarsity, 1991.

Graves, Allen W., A Church at Work: A Handbook of Church Polity, Nashville: Convention Press, 1972.

Greeleaf, Robert K., Servant Leadership: A Journey into the Nature of Legitiamte Power and Greatness, New York: Paulist Press, 1977.

Hartono, Chris, Peranan Organisasi Bagi Gereja, Jakarta: BPK Gunung Mulia, 1978.

Jonge de, Christian, Apa itu Calvinisme? Jakarta: BPK Gunung Mulia, 2011.

Napel, Henk ten, Kamus Teologi Inggris - Indonesia, Jakarta: BPK Gunung Mulia, 2002.

Parapak, Jonathan, Pembelajar dan Pelayan, Jakarta: Institut Darma Mahardika, 2002.

Rudge, Peter F., Management in the Church, London: McGraw-Hill Book Company, 1976. 
Schaller, Lyle E., \& Tidwell, Charles A., Creative Church Administration, Nashville: Abingdon Press, 1975.

Sinamo, Jansen dan Santoso, Agus, Pemimpin Kredibel, Pamimpin Visoner, Cet 2, Jakarta: Institut Darma Mahardika, 2012.

Tomatala, Yakob, Kepemimpinan yang Dinamis, Jakarta: Leadership Foundation, 1997.

Virgil, John, Kompleksitas Pengembangan Gereja, Jakarta: Yayasan Kasih Imanuel, 2001.

Web. https://www.mindtools.com/pages/article/newLDR 56.htm. 